\title{
CORRESPONDENCE
}

\section{Stem-cell decision is no threat to federal science funding}

As counsel for the researcher plaintiffs in the lawsuit against the US National Institutes of Health (NIH) on experiments using human embryonic stem cells, I write to correct your assertion that the progress of the suit poses a threat to "the very framework of federal funding for science" (Nature 466, 159; 2010).

As the US District Court for the District of Columbia held on 23 August (go.nature. com/1z6f5K), federal funding for embryonic stem-cell research violates Congress's prohibition against federal funding for "research in which a human embryo or embryos are destroyed, discarded, or knowingly subjected to risk of injury or death".

In its decision in June that the researcher plaintiffs had sufficient standing to challenge the $\mathrm{NIH}$ guidelines for human embryonic stem-cell research, the Court of Appeals did not suggest that researchers are "legally entitled to a certain portion of the funding pie" or "that changes in a federal agency's research priorities ... open the agency up to lawsuits".

Instead, the court faithfully applied a long line of cases, stretching back to the early 1970s. These consistently held that participants in regulated markets suffer injury when illegal changes in the regulatory scheme alter the competitive landscape - in this case, the increased competition for funding to support research on adult (as opposed to embryonic) stem cells. None of those cases invited runaway litigation against federal agencies, and the court in this case extended no such invitation.

What's more, the NIH deemed as "unresponsive to the issues at hand" many of the comments it received on its draft guidelines, which were opposed to the federal funding of human embryonic stem-cell research (see go.nature. com/nVJy5f). Under Congress's directions in the Administrative Procedure Act, an agency must consider relevant comments when promulgating a new rule.

If the researcher plaintiffs had been denied their day in court, no party would have had standing to rectify these injustices. Your readers might then have had a reason to be concerned about a possible threat to the federal funding of science.

Samuel B. Casey Advocates International, 9691 Main Street, Suite D, Fairfax, Virginia 22031, USA e-mail: sbcasey@ advocatesinternational.org

See Editorial, page 7, and News, page 12.

\section{Irish research cuts threaten economic recovery}

As Ireland officially emerges from its worst recession for 70 years, the government's commitment to reduce its economic reliance on tourism and agriculture and to develop a knowledge-based 'smart economy' is in peril. The threat comes from cuts in public-sector research funding and from the rationalization of scientific industry, notably in the pharmaceutical sector.

It was revealed in July that some 950 graduate student and postdoctoral research positions, crucial to the development of Ireland's smart economy, will be lost this year (see go.nature. com/3tXbVU). These posts represent a 33\% cut in just two years in the number of researchers funded by Science Foundation Ireland (SFI), a state body entrusted with the implementation of the government's strategy for science, technology and innovation. Last year, the SFI's budget for new researchers dropped by $80 \%$ from the previous year, and the trend is set to continue (Nature $\mathbf{4 6 3}$, 410-411; 2010).

Ireland's researchers are not alone in such experiences, but it is alarming that the cuts come at a time when multinational drug companies are undergoing largescale rationalization of their global workforces. The country has long been a hub for this sector because of its major tax incentives, good infrastructure and pool of talent.

Numbers of job losses are in the thousands as a result of recent acquisitions. For example, 18\% of Pfizer's cuts this year of 6,000 jobs worldwide were in Ireland. The country is being displaced by emerging economies such as those of India and the Far East, where costs are low.

The Irish government needs to reposition itself as a major player in this area by re-evaluating its commitment to research funding and to attracting foreign investment. Reviving the smart economy will improve the prospects of thousands of Irish scientists and engineers currently staring into the abyss of unemployment and emigration. Kevin Turner National University of Ireland, Galway, University Road, Galway, Ireland e-mail: kevinturner2006@gmail.com

\section{Games and play mean different things in an educational context}

In discussing the importance of computer games for conveying serious messages through play, Aleks Krotoski uses "play" and "games" interchangeably (Nature $466,695 ; 2010)$. However, this is incorrect in the context of human development: these terms denote separate constructs, with different ontogenies, proximal causes and functions.

Play is mainly a behaviour of juveniles and is not functional in its immediate environment; its benefits relate to creativity and novelty. Games are developed later in childhood and are governed by rules based on deduction; their benefits tend to be specific to the game's dimensions (such as hand-eye coordination). What Krotoski describes are games, not play: interaction with an end in mind.

This conflation is potentially damaging. Science can progress only if constructs are clearly delineated and used consistently; where there is deviation, definitions should be explicit. Inexact usage may also mislead policy-makers: take Krotoski's claim that "computer-based play can support learning in schools". To my knowledge, there is very little evidence that play, as defined here, affects school-based learning; where it does, it is limited to preschool children. But there is good evidence that games help school-age children.

\section{Anthony D. Pellegrini University of Minnesota, 56 East River Road, Minneapolis, Minnesota 55455, USA e-mail: pelle013@umn.edu \\ Mosquitoes: more likely nectar thieves than pollinators}

I suspect that Janet Fang's claim that "thousands of plant species" are pollinated by mosquitoes (Nature 466, 432-434; 2010) is an exaggeration. There are hardly any papers published on mosquitoes as pollinators, and only one plant species in North America - the orchid Platanthera obtusata - has been reported to be pollinated by these insects (J. R. Gorham Am. Midl. Nat. 95, 208-210; 1976).

Given the mismatch between mosquito morphology and most flowers, it is likely that they are stealing nectar without acting as pollinators.

David W. Inouye Department of Biology, University of Maryland, College Park, Maryland 20742, USA; and Rocky Mountain Biological Laboratory, Crested Butte, Colorado 81224, USA

e-mail:inouye@umd.edu

Contributions may be submitted to correspondence@nature.com; see go.nature.com/cMCHno.

Readers can now comment online on anything published in Nature: www.nature.com/nature. 